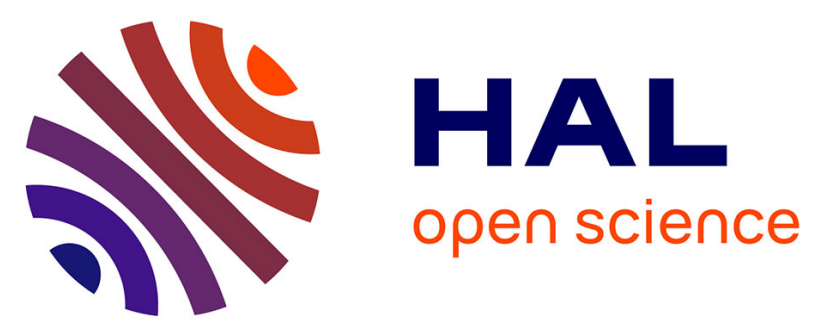

\title{
Impact of collagen confinement vs. ionic substitutions on the local disorder in bone and biomimetic apatites
}

Yan Wang, Stanislas von Euw, Guillaume Laurent, Charlene Crevant, Laure

Bonhomme-Coury, Marie-Madeleine Giraud-Guille, Florence Babonneau, Nadine Nassif, Thierry Azais

\section{To cite this version:}

Yan Wang, Stanislas von Euw, Guillaume Laurent, Charlene Crevant, Laure Bonhomme-Coury, et al.. Impact of collagen confinement vs. ionic substitutions on the local disorder in bone and biomimetic apatites. Materials Horizons, 2014, 1 (2), pp.224-231. 10.1039/c3mh00071k . hal-01275062

\section{HAL Id: hal-01275062 \\ https://hal.science/hal-01275062}

Submitted on 27 Sep 2018

HAL is a multi-disciplinary open access archive for the deposit and dissemination of scientific research documents, whether they are published or not. The documents may come from teaching and research institutions in France or abroad, or from public or private research centers.
L'archive ouverte pluridisciplinaire HAL, est destinée au dépôt et à la diffusion de documents scientifiques de niveau recherche, publiés ou non, émanant des établissements d'enseignement et de recherche français ou étrangers, des laboratoires publics ou privés. 


\title{
Impact of Collagen Confinement vs. Ionic Substitutions on the local disorder in Bone and Biomimetic Apatites
}

\author{
Yan Wang, Stanislas Von Euw, Guillaume Laurent, Charlène Crevant, Laure Bonhomme-Coury, \\ Marie-Madeleine Giraud-Guille, Florence Babonneau, Nadine Nassif* and Thierry Azaïs* \\ UPMC Univ Paris 06 \& CNRS, UMR 7574, Chimie de la Matière Condensée de Paris, Collège de \\ France, 11 Place Marcelin Berthelot, F-75005 Paris, France
}

*Corresponding Authors: nadine.nassif@upmc.fr and thierry.azais@upmc.fr 


\begin{abstract}
The aim of the study is to identify some key physico-chemical parameters that influence the structural characteristics of carbonated hydroxyapatite and, in particular, the so-called "poorly crystallized" nature of biological hydroxyapatite. Here, we investigate this feature by 1D and 2D ${ }^{1} \mathrm{H}-{ }^{31} \mathrm{P}$ solid-state NMR experiments through the evaluation of the local order/disorder around the phosphate and the hydroxyl ions in the crystalline apatitic core as well as the quantification of the amorphous layer. The study relies on a large variety of apatite models, i.e. from pure highly crystalline apatites to tissue-like models, as well as on fresh intact bone. We show that both collagen confinement and ionic substitutions have an impact on the structural characteristics of apatites. Nevertheless, while collagen confinement appears predominant at the initial stages of apatite formation, these characteristics are later dominated by the ionic substitutions, specifically from carbonate ions. We show that an amount of $\mathrm{CO}_{3}{ }^{2-}$ around 7-8 $w t \%$ is necessary to set biomimetic apatite models possessing similar structural characteristics to those found for bone mineral.
\end{abstract}




\section{Introduction}

Skeletal materials found in living organisms offer a variety of complex and subtle architectures with various specific properties. One remarkable example of a natural composite material is bone. The bone mineral platelets are located in an organic matrix where Type I collagen (i.e. its main component) assemble into fibrils that further organize to form a dense tridimensional network. ${ }^{1}$ The initial steps of mineralization are first expected to occur within the fibril in confined well-distributed gaps $(\sim 40 \mathrm{~nm})$ of axial periodicity $(67 \mathrm{~nm})$, described as nucleation sites (i.e. intra-fibrillar mineralization), ${ }^{2,3}$ then continue along the collagen fibrils. Nevertheless, crystals may also nucleate from inter-fibrillar collagen sites. ${ }^{4}$ Inside this 3D restricted volume, confinement effect may occur on protein's activities as well as on mineral formation (nucleation and growth). Noticeably, non-collagen proteins (NCPs) can show opposite activities depending on their surrounding state, either in diluted or condensed conditions. 56

Bone minerals consist of an inorganic calcium phosphate phase for which the composition derives from the stoichiometric hydroxyapatite, $\mathrm{Ca}_{10}\left(\mathrm{PO}_{4}\right)_{6}(\mathrm{OH})_{2}$ (HAP). Bone apatite is structurally disordered, and compositionally nonstoichiometric due to the incorporation of a substantial amount of anionic $\left(\mathrm{CO}_{3}{ }^{2-}\right)$ and cationic substitutions $\left(\mathrm{Na}^{+}, \mathrm{Mg}^{2+}\right)$ into the crystalline structure. ${ }^{7}$ The most noticeable substitution is the replacement of the $\mathrm{PO}_{4}{ }^{3-}$ (B-type substitution) and/or $\mathrm{OH}^{-}$(A-type substitution) anions by carbonate ions $\mathrm{CO}_{3}{ }^{2-}$ (up to 5-8 weight \%). Biological particles are nanosized platelets $(\sim 10 \times 25 \times 50 \mathrm{~nm})^{1}$ displaying a crystalline apatitic core and characterized by a so-called "hydrated disordered surface layer" composed mainly of divalent species such as $\mathrm{Ca}^{2+}, \mathrm{HPO}_{4}{ }^{2-}, \mathrm{CO}_{3}{ }^{2-}$ and structural $\mathrm{H}_{2} \mathrm{O} .{ }^{8}$ Overall, this leads to the following general formula: $\mathrm{Ca}_{8.3} \square_{1,7}\left(\mathrm{PO}_{4}\right)_{4.3}\left(\mathrm{HPO}_{4} \text { or } \mathrm{CO}_{3}\right)_{1.7}\left(\mathrm{OH} \text { or } 1 / 2 \mathrm{CO}_{3}\right)_{0,3} \square_{1.7} \cdot{ }^{9}$ Hence, in contrast to stoichiometric Hap, bone mineral is often described as "poorly crystallized" calciumdeficient apatite. The $c$-axis of apatite crystals aligns with the collagen fibril direction. Their final structural features provide specific properties to bone, in particular: ( $i$ ) the poorly crystallized nature of the bone mineral particles favors the resorption/remodelling process; ${ }^{1}$ (ii) the hydrated disordered surface layer is proposed to act as an ion reservoir; ${ }^{10}$ (iii) the intimate 3D association between the mineral, the organic part and water enhances the mechanical properties. ${ }^{11,12}$ More recently, it was shown that the hydrated disordered layer identified as an amorphous calcium phosphate (ACP) related phase is involved in the stacking of the apatite platelets along their $c$-axis in the presence of water. ${ }^{8}$

In the literature, various analytical tools are used to characterize the intrinsic structural disorder of carbonated Hap. Among those, X-ray diffraction provides a typical pattern of bone apatite displaying very broad reflections compared to stoichiometric Hap. ${ }^{1}$ Solid state NMR 
(ssNMR) is also widely used for the investigation of the bone structure,13, 14 its hydration level,15 and its organo-mineral interface. ${ }^{16-19}$ This spectroscopy is sensitive to the structural disorder since it is also directly related to the line width of the resonances, which are, in that case, dominated by a distribution of chemical shifts. Thus, 1D ssNMR of ${ }^{1} \mathrm{H}$ and ${ }^{31} \mathrm{P}$ nuclei allows the investigation of the local environment around the phosphate ${ }^{20}$ and the hydroxyls ions ${ }^{21}$ of bone apatite, respectively. In particular, the ${ }^{31} \mathrm{P}$ spectrum of bone mineral displays a typical broad resonance 22 reflecting a highly disordered environment for the phosphate groups compared to stoechiometric HAP.

For a deeper understanding of bone biomineralization mechanisms, in vitro models are still needed since the study of living bone remains difficult without chemical and/or biological treatments. Nevertheless, synthesis of biomimetic HAP particles that exhibit the main structural characteristics of bone mineral (i.e. nanosized platelets incorporating a high amount of $\mathrm{CO}_{3}{ }^{2-}$ and displaying a hydrated disordered surface layer) is not straightforward. Nanorods or elongated particles vs. HAP platelets are usually precipitated in vitro. ${ }^{23}$ Moreover, ionic substitutions in hydroxyapatite, in particular by carbonates ions, are difficult to control and hard to obtain in large amounts. ${ }^{23}$ The presence of an hydrated disordered surface layer is also difficult to apprehend. However, it partly explains why the physico-chemical parameters influencing the structural characteristics of bone apatite are not well-defined.

In previous work, the use of appropriate models, ${ }^{24}$ i.e. a bone tissue-like matrix, studied by sSNMR was useful to show that the collagen matrix not only controls the size and the threedimensional distribution of apatite at different length scales, but has a further impact on the local hydrated environment of phosphate ions. ${ }^{22,}{ }^{25}$ It was shown that the proportion of the hydrated amorphous calcium phosphate layer $v$ s. the crystalline apatitic core depends on the 3D spatial confinement set by the dense fibrillar scaffold. ${ }^{22}$

Here, we investigate through ssNMR the impact of such collagen confinement $v s$. the impact of ionic substitutions (in particular, the role of carbonate ions) on the structural characteristics of apatite. We show that both influence the so-called "poorly crystallized" nature of the particles as well as the extent of the hydrated disordered layer. However, the confinement effect is minimized with the increase of ionic substitutions. Hence, the structural characteristics of bone apatite seem to be determined by the incorporation of carbonate ions both in the crystalline core (as substitution ions) and in the amorphous layer while the impact of the 3D confinement in the dense collagen matrix might be of importance at the first stage of particles' nucleation.

Our studies rely on the use of different models including the bone tissue-like matrices (Coll/CHA and Coll/CHA(SBF) $)^{22}$ and pure synthetic apatites from biomimetic (CHA and CHA-SBF) ${ }^{8,26}$ to more crystalline ones (HA, cHA-3.6, cHA-5.2, cHA-8.1). ${ }^{27}$ The extended sample array provides a larger variety of particles' morphologies, carbonate content, and crystalline structures 
(according to $1 \mathrm{D}$ and $2 \mathrm{D}$ multinuclear $\left({ }^{1} \mathrm{H},{ }^{31} \mathrm{P}\right)$ solid-state NMR, powder XRD and TEM) that are compared to fresh bone sample to investigate the importance of the related effects (confinement $v s$. ionic substitutions) in vivo. In particular, we demonstrate that the specific spectral features of bone mineral can be restored as soon as the proportion of $\mathrm{CO}_{3}{ }^{2-}$ ions is increased up to 7-8 wt.\%, a value close to the proportion found in bone mineral. ${ }^{1}$

This is principally established here through $2 \mathrm{D}{ }^{1} \mathrm{H}-31 \mathrm{P}$ ssNMR experiments based on the ${ }^{1} \mathrm{H}-31 \mathrm{P}$ dipolar coupling that gives access to the spatial proximity between the two nuclei. ${ }^{28} 2 \mathrm{D}\left\{{ }^{1} \mathrm{H}\right\}{ }^{31} \mathrm{P}$ HetCor experiment is used to correlate phosphate to their respective proton environments. ${ }^{29-31}$ This method leads to the spectral differentiation of the ${ }^{31} \mathrm{P}$ and ${ }^{1} \mathrm{H}$ resonances coming from the apatitic core (essentially composed of $\mathrm{PO}_{4}{ }^{3-}$ and $\mathrm{OH}^{-}$species) from those related to the hydrated disordered layer (essentially composed of $\mathrm{HPO}_{4}^{2-}$ and $\mathrm{H}_{2} \mathrm{O}$ species) as previously shown for bone 8,22 and synthetic apatite..$^{32}$

\section{Materials and Methods}

Synthesis of apatites and hybrid models:

CHA: The nanosized carbonated HAP $\left(\mathrm{CO}_{3}{ }^{2-}\right.$ content $\sim 5 \mathrm{wt} . \%$ from TGA $)$ was obtained at ambient temperature by an ammonia vapors diffusion method ${ }^{26}$. Briefly, a solution of $110 \mathrm{mM}$ $\mathrm{CaCl}_{2}, 33 \mathrm{mM} \mathrm{NaH}_{2} \mathrm{PO}_{4}$, and $33 \mathrm{mM} \mathrm{NaHCO} 3$ was prepared in $500 \mathrm{mM}$ acetic acid (carbonate-tophosphate molar ratio $\mathrm{C} / \mathrm{P}=1)$. Two flasks $(35 \mathrm{~mL}, h=50 \mathrm{~mm})$ containing these solutions (20 $\mathrm{mL}$ ) and covered by perforated Parafilm (to slow down the gas diffusion) were placed into a closed chamber $\left(1000 \mathrm{~cm}^{3}\right)$. The CHA precipitation was triggered via the slow increase of the $\mathrm{pH}$ solution by the vapors of a fresh ammonia aqueous solution (30 wt.\%, $8 \mathrm{~mL}$ ) also placed in the chamber. A few hours after ammonia introduction, precipitation occurs in the solution. After complete gas diffusion ( $\mathrm{pH}$ 10), the solids were washed and centrifuged (6000 rpm, $10 \mathrm{~min}$ ) first in distilled water and then in ethanol to remove the non-precipitated salts. The recovered crystals were dried at $37^{\circ} \mathrm{C}$ for 3 days before characterization.

CHA-SBF: nanosized carbonated Hap are precipitated directly from a SBF solution ${ }^{8}$ possessing a composition close to human blood plasma. A solution 1.5 times more concentrated compared to standard SBF is prepared $(1.5 \times \mathrm{SBF}) .{ }^{33}$ The composition of the solution is detailed in Table S1 ( $/ \mathrm{P}=4.2)$. $1 \mathrm{~L}$ of the solution is frozen at $-20^{\circ} \mathrm{C}$ for 1 night. Then, the solution is thawed at $5^{\circ} \mathrm{C}$. The resulting particles are recovered by centrifugation $(6000 \mathrm{rpm}, 10 \mathrm{~min})$ and 
then dried at $37^{\circ} \mathrm{C}$ for 3 days before characterization. The fraction of carbonate ions is around 7 wt. $\%$, from TGA.

Coll/CHA and Coll/CHA(SBF): For the hybrid matrices, the Hap precipitation occurred inside a dense 3D collagen matrix adopting a cholesteric organization. ${ }^{22}, 34$ Coll/CHA: $3 \mathrm{mg} / \mathrm{mL}$ soluble acidic collagen solution ( $0.5 \mathrm{mM}$ acetic acid) mixed with the CHA precursor solution $(0.5$ $\mathrm{mM}$ acetic acid) was continually injected in a closed dialysis chamber in the rate range of $1 \mu \mathrm{L} / \mathrm{min}-15 \mathrm{~mL} / \mathrm{min}$ for 8 days. The reverse dialysis process was set against polyethylene glycol (PEG, $35 \mathrm{kDa}$, Fluka) dissolved in $0.5 \mathrm{M}$ acetic acid up to $300 \mathrm{mg} / \mathrm{mL}$. After the total amount of solution was injected, the dialysis was continued for 4-8 days in order to obtain a homogeneous concentration in the samples. The $\mathrm{pH}$ was then increased to 9-10 by ammonia gas diffusion for 4-8 days to induce collagen fibrillogenesis together with the Hap precipitation. The degree of mineralization of the resulting hybrid matrix is about $5 \mathrm{wt} . \%$ from TGA. The mineral was mainly deposited into gap regions of the collagen fibrils. Coll/CHA(SBF): The mineral charge of the previous matrix was increased at $37^{\circ} \mathrm{C}$ under mild rotative stirring (200 rpm) by immersion in the $1.5 \times \mathrm{SBF}$ solution $(45 \mathrm{~mL}$ ). The $1.5 \times \mathrm{SBF}$ solution was renewed every 4 days for 16 days. The degree of mineralization of the resulting hybrid matrix is about $50 \mathrm{w} \%$ close to the value determined for compact bone.

cHA-X: The synthesis has been realized following the procedures described in the literature. ${ }^{27}$ The water used in the different steps of the synthesis has been boiled and then cooled under $\mathrm{N}_{2}$ bubbling in order to avoid the dissolution of $\mathrm{CO}_{2}$ from the atmosphere. Briefly, an aqueous solution of the phosphate and carbonate precursors is prepared by mixing a solution of $\left(\mathrm{NH}_{4}\right)_{2} \mathrm{PO}_{4}(300 \mathrm{mM})$ and a solution of $\mathrm{NaHCO}_{3}$. The $\mathrm{pH}$ was adjusted to 10 by the addition of aqueous $\mathrm{NH}_{3}$ (30 wt.\%). This mixed solution was added to a solution of $\mathrm{Ca}\left(\mathrm{NO}_{3}\right)_{2} \cdot 4 \mathrm{H}_{2} \mathrm{O}(100 \mathrm{~mL}$; $500 \mathrm{mM}$ ) at $3 \mathrm{~mL} / \mathrm{min}$ by an automatic titrator (Titrando 808, Metrohm). The mixture was stirred during $24 \mathrm{~h}$. The resulting particles were recovered by centrifugation ( $6000 \mathrm{rpm}, 10 \mathrm{~min}$ ) and then dried at $105^{\circ} \mathrm{C}$ for 3 days and heated at $400^{\circ} \mathrm{C}$ for 3 hours before characterization. The concentrations of the $\mathrm{NaHCO}_{3}$ solution were 75, 150 and $300 \mathrm{mM}$ and lead to an incorporation of 3.6, 5.2 and $8.1 \mathrm{w} \%$ of carbonate ions, respectively, as determined by elemental analysis. The powders are noted cHA-3.6, cHA-5.2, cHA-8.1, respectively. Without the addition of the $\mathrm{NaHCO}_{3}$ solution and despite all the precaution used to avoid the dissolution of $\mathrm{CO}_{2}$, a tiny amount of $\mathrm{CO}_{3}{ }^{2-}$ is determined by elemental analysis ( $\left.<1 \mathrm{w} \%\right)$. The corresponding powder is noted HA. The concentrations used for the synthesis are summarized in Table S2. 


\section{Bone samples preparation:}

Bone samples were harvested from healthy 2 years old French ewes. Bone was extracted from the proximal part of the diaphysis and distal epiphysis of humerus and femur. The project was reviewed and approved by the IMM Recherche's Institutional Animal Care and Use committee (IACUC) prior to the initiation of this study. The animal research center (IMMRecherche) received an agreement ( $\left.n^{\circ} 75-14-01\right)$ on September 08th, 2008 for a period of 5 years by the "Sous-Direction de la protection Sanitaire" of the French Authorities. The NMR study was performed on fresh intact bone within $2 \mathrm{~h}$ after extraction (without any treatment) to prevent uncontrolled dehydration of the sample and to prevent any alteration by chemical pretreatment. $8,15,22,29$

Analysis:

Solid State NMR. ${ }^{1} \mathrm{H}$ and ${ }^{31} \mathrm{P}$ solid state NMR experiments were recorded on a Avance 300 Bruker spectrometer operating at $\left({ }^{1} \mathrm{H}\right)=300.13 \mathrm{MHz}$ and $\left({ }^{31} \mathrm{P}\right)=121.5 \mathrm{MHz}$. Dry powders $(\mathrm{HA}$, cHA-3.6, cHA-5.2, cHA-8.1) were packed in $4 \mathrm{~mm}$ (O.D.) zirconia rotors and spun at $14 \mathrm{kHz}$. Wet powders (CHA and CHA-SBF) were packed and placed in-between two Teflon spacers into a 4 $\mathrm{mm}$ (O.D.) zirconia rotor. They were wetted with $10 \mu \mathrm{L}$ of double distilled water and then spun at $8 \mathrm{kHz}$. Wet samples (fresh bone, Coll/CHA, Coll/CHA(SBF)) were placed in-between two Teflon spacers into a $4 \mathrm{~mm}$ (O.D.) zirconia rotors and spun at $8 \mathrm{kHz}$. The NMR study was performed within 2 hours after extraction from untreated bone. $t_{90^{\circ}}\left({ }^{1} \mathrm{H}\right)$ and $t_{90^{\circ}}\left({ }^{31} \mathrm{P}\right)$ were $4.5 \mu \mathrm{s}$ and $5.5 \mu \mathrm{s}$, respectively. ${ }^{1} \mathrm{H}$ and ${ }^{31} \mathrm{P}$ chemical shift was referenced ( $\left.\delta=0 \mathrm{ppm}\right)$ to TMS and 85 wt.\% aqueous $\mathrm{H}_{3} \mathrm{PO}_{4}$, respectively. ${ }^{31} \mathrm{P}$ quantitative MAS experiments were single pulse experiments (recycle delay $\mathrm{RD}=200 \mathrm{~s}$ ). ${ }^{1} \mathrm{H}-{ }^{31} \mathrm{P}$ HetCor experiments parameters were the followings: (i) CHA, CHA-SBF, fresh bone, Coll/CHA and Coll/CHA(SBF): RD $=3.5$ s, contact time $\mathrm{CT}=10 \mathrm{~ms}, 400$ transients for each $128 \mathrm{t}_{1}$ increments; (ii) HA, cHA-3.6, cHA-5.2, cHA-8.1: RD = 2 $\mathrm{s}$, contact time CT $=1 \mathrm{~ms}, 232$ transients for each $128 \mathrm{t}_{1}$ increments. The ${ }^{31} \mathrm{P}$-filtered ${ }^{1} \mathrm{H}$ spectra were recorded through a $\left\{{ }^{1} \mathrm{H}^{-31} \mathrm{P}\right\}{ }^{1} \mathrm{H}$ Double CP MAS experiment with a first $\mathrm{CT}_{1}=\mathrm{CT}_{2}=10-15$ $\mathrm{ms}$ in order to maximize the hydroxyls resonance.

Powder X-ray diffraction (XRD) diagrams of all samples were performed on a Bruker D8 $\mathrm{X}$-ray diffractometer operating in the reflection mode at $\mathrm{CuK \alpha}$ radiation with $40 \mathrm{kV}$ beam voltage and $40 \mathrm{~mA}$ beam current. The data were collected in the $5-57^{\circ}$ range $(2 \theta)$ with steps of $0.01^{\circ}$ and a counting time of $9 \mathrm{~s}$. The 9-432 JCPDS file was used to identify hydroxyapatite.

For TEM studies, the apatite samples were dispersed in ethanol. Few drops of the 
resulting dispersion were deposited on a carbon coated copper grid. After solvent evaporation, TEM investigations were performed with a FEI TECMAI G2 Spirit Twin electron microscope operating at $120 \mathrm{kV}$. For the hybrid matrices (Coll/CHA and Coll/CHA(SBF)), fresh bone samples were fixed in $2.5 \%$ glutaraldehyde. After washing in a cacodylate/saccharose buffer solution (0.05 M/0.6 M, pH 7.4), the samples were directly dehydrated (no staining) through successive ethanol baths (50\%, 70\%, 95\%, and 100\%) and embedded in araldite for ultrathin sectioning (Ultracut Reichert Young). TEM investigations were performed on thin sections ( 80 nm) deposited on copper grids (without staining).

Elemental analyses were performed by the Service Central d'Analyse of CNRS, Villeurbanne, France (Ca and P: ICP AES, ICAP 6300 from Thermofisher Scientific; C: homemade microanalysor).

Thermogravimetric analysis (TGA) was performed on a thermo-microbalance instrument (NETZSCH STA 409PC) with the synthetic mineralized matrices. The measurement was performed from room temperature to $1000^{\circ} \mathrm{C}$ in an oxidizing atmosphere with a heating rate of $5^{\circ} \mathrm{C} / \mathrm{min}$.

\section{Results and Discussion}

\section{Confinement effect in collagen on apatite formation}

To probe the impact of spatial confinement induced by collagen, two models were first compared: HAP particles were precipitated from the same mother solution in the absence (CHA) or in the presence of collagen (Coll/CHA). The HAP particles nucleate starting from an aqueous solution containing ionic precursors of carbonated Hap $\left(\mathrm{Ca}^{2+}, \mathrm{PO}_{4}{ }^{2-}\right.$ and $\left.\mathrm{CO}_{3}^{2-}\right)$. $\mathrm{CHA}$ was identified as biomimetic in a previous study. ${ }^{26}$ Coll/CHA is characterized by (i) a 3D dense and hierarchically organized collageneous fibrillar network ${ }^{34}$ mimicking what is found in compact bone (cholesteric, aligned and isotropic domains) and (ii) a low mineralization degree $(\sim 5$ wt.\%). ${ }^{22}$ TEM observations of unstained samples (Fig. 1a) show that this matrix exhibits both ( $i$ ) lateral packing of small crystals (white arrow) across the diameter of the collagen fibrils that resemble the early stages of intrafibrillar mineralization, as described in the 2D channel model by Hodge and Petruska; ${ }^{35}$ and (ii) the continuous apatite crystal deposition into both the intermolecular spaces between collagen molecules and the interfibrillar spaces of collagen fibrils (yellow arrow) that may illustrate the later stages of calcification. The benefit of using such matrix here is the presence of very small "dot-like" crystals within the collagen fibrils 
remarkably similar to the very early stages of normal in vivo calcification of embryonic chick bone reported by Fitton-Jackson ${ }^{2}$ or in vitro mineralization of decalcified bone. ${ }^{1}$ In contrast, CHA display a platelet's morphology (Fig. 1b).

Previous results emphasized the need to keep bone in its native hydration state to avoid artifacts coming from dehydration and thus, misleading interpretations. Hence, Coll/CHA matrix was kept in its hydrated state while CHA powder was wetted for safe comparison. The analyses were performed after the same time of maturation ( 6 days). Figure $1 \mathrm{c}$ displays the 1D ${ }^{31} \mathrm{P}$ MAS spectrum of Coll/CHA and CHA that exhibits a resonance at $2.9 \mathrm{ppm}$ characteristic of carbonated apatite. ${ }^{26}$ We note that the resonance of Coll/CHA is significantly broader than CHA (LW $=260$ $\mathrm{Hz} v s .180 \mathrm{~Hz}$, respectively). The 2D $\left\{{ }^{1} \mathrm{H}\right\}{ }^{31} \mathrm{P}$ HetCor spectra of the two samples are also similar (Fig. 1d, 1e) and exhibit two cross-peaks $\left(\delta\left({ }^{31} \mathrm{P}\right) \sim 2.9 \mathrm{ppm}\right)$ that correspond to $(i)$ apatitic phosphate correlation with $\mathrm{OH}^{-}$ions $\left(\delta\left({ }^{1} \mathrm{H}\right)=0 \mathrm{ppm}\right)$ and (ii) phosphate from the outer layer correlating with water molecules $\left(\delta\left({ }^{1} \mathrm{H}\right)=4.85 \mathrm{ppm}\right)$. This feature demonstrates that the HAP particles in both samples are composed of an apatitic core surrounded by an hydrated disordered layer as found in bone mineral. ${ }^{22}$ Nevertheless, the ${ }^{31} \mathrm{P}$ projections relative to each $\mathrm{P}$ groups (apatitic core and outer layer) confirm the tendency observed above since they are globally broader for Coll/CHA (LW ${ }^{31} \mathrm{P}$ apatitic core $=200 \mathrm{~Hz}$; LW ${ }^{31} \mathrm{P}$ disordered layer $=490 \mathrm{~Hz}$ ) compared to CHA (LW ${ }^{31} \mathrm{P}$ apatitic core $=140 \mathrm{~Hz}$; LW ${ }^{31} \mathrm{P}$ disordered layer $=430 \mathrm{~Hz}$ ) (Table 1). Concerning the apatitic core, this reflects a higher degree of disorder of the apatitic lattice for Coll/CHA which is somehow intriguing since the Hap particles of both samples are precipitated from the same mother solution (Table S1).

Due to the presence of collagen and water that dominates the ${ }^{1} \mathrm{H}$ spectrum, the direct acquisition of a ${ }^{1} \mathrm{H}$ MAS spectrum of Coll/CHA do not allow the identification of the $\mathrm{OH}^{-}$resonance. Thus, we used ${ }^{31} \mathrm{P}$-filtered experiments to record direct ${ }^{1} \mathrm{H}$ spectra through a $\left\{{ }^{1} \mathrm{H}-31 \mathrm{P}\right\}{ }^{1} \mathrm{H}$ Double $\mathrm{CP}$ experiment. ${ }^{36}$ The use of long contact times $(10 \mathrm{~ms})$ allows the specific spectral edition of the hydroxyl resonance. Figure $1 \mathrm{f}$ displays the $\left\{{ }^{1} \mathrm{H}^{-31} \mathrm{P}\right\}{ }^{1} \mathrm{H}$ Double CP spectra of CHA and Coll/CHA. A similar trend for the ${ }^{1} \mathrm{H}$ apatitic $\mathrm{LW}$ is evidenced by the $\mathrm{OH}^{-}$resonance that is twice broader for Coll/CHA compared to CHA (Table 1). This also highlights the consequence of the confinement on the structural characteristics of HAP particles within the 3D dense collagenous matrix that increases the local disorder in the apatitic lattice.

The proportion of surface vs. core species detected by 2D NMR is higher for Coll/CHA compared to $\mathrm{CHA}$ as seen on the ${ }^{1} \mathrm{H}$ projection (the HetCor experiments have been recorded with the same contact time $t_{C P}=10 \mathrm{~ms}$ ). The estimation of the relative amount of surface $v s$. apatitic species can be achieved by the fitting of the 1D ${ }^{31} \mathrm{P}$ spectra using the ${ }^{31} \mathrm{P}$ line shapes extracted from the 2D HetCor spectra (Fig. S1). A greater amount of phosphate ions is found in the outer layer vs. in the apatitic core for Coll/CHA compared to CHA $(60 / 40 \pm 5$ and 35/65 \pm 5 , 
respectively; Table 1). This result can be directly related to the size of the HAP particles. CHA platelets (Fig.1a) appear bigger in size than those located within the dense collagen matrix (Coll/CHA) (Fig. 1b). This size effect enhances the proportion of surface species for the small particles. It is worth mentioning that a kinetic effect on the crystal's growth and maturation may occur in the presence of collagen although Coll/CHA samples appear stable for a few months.

These results emphasize the impact of confinement by the surrounding 3D collagen matrix on the initial steps of HAP formation in Coll/CHA that may occur in intra- $(\sim 40 \mathrm{~nm})$ and /or interfibrillar spaces $(\sim 1.5 \mathrm{~nm})$.

\section{Influence of ionic substitutions on apatite formation}

When Coll/CHA is immersed under 'dynamic' conditions in a concentrated simulated body fluid (SBF) ${ }^{22}$, i.e. a serum-like solution, ${ }^{33}$ the resulting matrix Coll/CHA(SBF) possesses a mineral content ( $\sim 50 \mathrm{wt} . \%)$ close to that described for mature bone. The HAP particles in Coll/CHA(SBF) appear with irregular edges and in the same size range as that found in bone. ${ }^{3}$ They are aligned with a preferred (002) orientation along the main axis of the collagen fibrils (Fig. 2a) similarly to bone mineral (Fig. 2b). Significantly, it was shown that the 1D ${ }^{31} \mathrm{P}$ spectra of Coll/CHA(SBF) and mature (intact) fresh bone are identical (Fig. 2d). ${ }^{22}$ They exhibit a single slightly asymmetric resonance at $3.2 \mathrm{ppm}$ relatively broad compared to CHA and Coll/CHA (LW $=340$ vs. 180 and $260 \mathrm{~Hz}$, respectively). Hence, the Coll/CHA(SBF) matrix is an appropriate model to assess the later stages of bone HAP particles formation.

To distinguish a probable effect of ionic substitutions $v s$. the effect of collagen confinement on apatite formation, Coll/CHA(SBF) and mature (intact) fresh bone were compared to HAP precipitated directly from SBF (CHA-SBF). Under such conditions, the $\mathrm{Ca}^{2+}, \mathrm{PO}_{4}{ }^{2-}$ and $\mathrm{CO}_{3}{ }^{2-}$ precursors are in a lower concentration than previously used for Coll/CHA and CHA. The advantage of using CHA-SBF (Fig. 2c) is twofold: ( $i$ ) the size of the particles appears closer to bone apatite compared to CHA and (ii) the in vitro simulations appear closer to the in vivo conditions thanks to the ionic composition of the mother solution. Here, the effect of collagen confinement is excluded since CHA-SBF is precipitated without collagen.

Interestingly, the 1D ${ }^{31} \mathrm{P}$ NMR spectra of fresh bone and Coll/CHA(SBF) are identical to CHA-SBF

(Fig. 2d). This result hints that the spatial confinement which affects the HAP platelets during their formation inside the 3D dense collagen matrix does not influence the ${ }^{31 P}$ line shape in contrast to Coll/CHA and CHA. Thus, it seems that the line shape is strictly determined by the ionic composition of the mother solution i.e. the biological serum for the bone and the SBF (for which the ionic composition is close to the biological serum) for Coll/CHA(SBF) and CHA-SBF. 
The three spectra display a characteristic shoulder (arrows) on the left side of the resonance whereas it is not observed for Coll/CHA and CHA. It is worth mentioning that such line shape is also observed for different mammalian bone samples (including bovine, rat and human bone). ${ }^{29}$, ${ }^{37}$ Hence, this may be the hallmark of in vivo-like bone mineral for future studies.

Figure 2e displays the $\left\{{ }^{1} \mathrm{H}-{ }^{31} \mathrm{P}\right\}{ }^{1} \mathrm{H}$ Double CP spectra of bone, Coll/CHA(SBF) and CHA$\mathrm{SBF}$. The signal of hydroxyl ions is broad in accordance with ${ }^{31} \mathrm{P}$ results. However, interestingly, the samples display complex line shape composed of at last 3 components with variable relative intensities. At this stage of study, it is difficult to assign precisely these signals that correspond to $\mathrm{OH}^{-}$ions in the diverse environments. Surprisingly, no difference was observed through ${ }^{31} \mathrm{P}$ NMR, while it is interesting to point out that they exhibit different ${ }^{1} \mathrm{H}$ spectra. This means that ${ }^{1} \mathrm{H}$ NMR is more sensitive than ${ }^{31} \mathrm{P}$ NMR regarding the local disorder induced by the precipitation conditions of HAP.

Figure 3a displays the 2D $\left\{{ }^{1} \mathrm{H}\right\}^{31} \mathrm{P}$ HetCor spectrum of wetted CHA-SBF. The two phosphate resonances are detected: $(i)$ apatitic $\mathrm{PO}_{4}{ }^{3-}$ ions $\left(\delta\left({ }^{31} \mathrm{P}\right)=3.0 \mathrm{ppm}\right)$ correlating with $\mathrm{OH}^{-}$ions $\left(\delta\left({ }^{1} \mathrm{H}\right)=0 \mathrm{ppm}\right)$ and (ii) phosphates from the outer disordered layer $\left(\delta\left({ }^{31} \mathrm{P}\right)=3.2 \mathrm{ppm}\right)$ that correlate with water molecules $\left(\delta\left({ }^{1} \mathrm{H}\right)=4.85 \mathrm{ppm}\right)$. The phosphate signal from the outer disordered layer is slightly shifted and associated to a line width significantly broader than the apatitic one (LW ${ }^{31} \mathrm{P}$ apatitic core $=290 \mathrm{~Hz} ; \mathrm{LW}{ }^{31} \mathrm{P}$ disordered layer $=660 \mathrm{~Hz}$ ). The close chemical shifts observed between these different species may be determined by the establishment of some H-bounds as proposed for octacalcium phosphate Davies et al. U. Am. Chem. Soc. 2012, 134(30), 12508-12515). ${ }^{38}$ Thus, the shoulder on the left side of the ${ }^{31 P}$ MAS spectrum is arising from the resonance of the surface layer phosphates ions (arrow on the ${ }^{31} \mathrm{P}$ HetCor projections). The ${ }^{31} \mathrm{P}$ line shapes extracted from the ${ }^{31} \mathrm{P}$ projections at $\delta\left({ }^{1} \mathrm{H}\right)=0$ and 4.85 ppm allows the fitting of the 1D ${ }^{31} \mathrm{P}$ spectrum. The relative amount of phosphate ions in both regions is ( ${ }^{31} \mathrm{P}$ apatitic/31P surface) $\sim 55 / 45$ (Table 1). The $2 \mathrm{D}\left\{{ }^{1} \mathrm{H}\right\}^{31} \mathrm{P}$ HetCor spectra of Coll/CHA(SBF) (Fig. 3b) and intact fresh bone (Fig. 3c) are similar and lead to similar conclusions.

Hence, as previously demonstrated,22 there is an impact of the collagen confinement on apatite formation at the atomic scale. However, this effect appears to be necessary only at the initial formation steps of the bone apatite mineral since the collagen confinement does not affect neither the size of the HAP particles nor the proportion of amorphous layer vs. the apatitic domain. Here, we show that this latter characteristic may actually be determined by the ionic composition of the mother solution. 
Comparison of the ${ }^{31} \mathrm{P}$ apatitic core signal of the pure apatite powders, CHA vs. CHA-SBF, show that the line width is broader for CHA-SBF (Table 1). Thus, the local disorder around the phosphate ions in the apatitic lattice is higher. This could be due to an effect of maturation that would increase the crystallinity as soon as the time of maturation of the particles in solution is increased. ${ }^{10}$ However, this assumption appears unlikely since the time of maturation is nearly the same for both samples. Thus, it suggests that this is due to the ionic substitutions in the apatitic lattice. As the SBF is composed of many ions that are known to be present as ionic substituents in bone mineral, various substitutions can be envisaged such as $\mathrm{Na}^{+}, \mathrm{CO}_{3}{ }^{2-}, \mathrm{Mg}^{2+}, \mathrm{K}^{+}$ and $\mathrm{Cl}$. They might be responsible for the structural disorder of the apatitic lattice as already reported for carbonate ions. ${ }^{39}$ Furthermore, the insertion of cations can participate in the apparent depletion of $\mathrm{OH}^{-}$ions in the HAP lattice of bone mineral. ${ }^{29}, 40$ The fact that the $\mathrm{OH}^{-}$ resonance is barely visible in ${ }^{1} \mathrm{H}$ MAS spectrum of CHA-SBF similarly to bone mineral strengthens this assumption (Fig S2).

As carbonate ions are the most important ionic substitutions in bone (5-8 wt \%), we pursued the study to clarify their role in the related NMR observations.

\section{Influence of the $\mathrm{CO}_{3}{ }^{2-}$ content on apatite formation}

Different syntheses of carbonated HAP were achieved in incorporating various amounts of $\mathrm{CO}_{3}{ }^{2-}(\mathrm{cHA}-\mathrm{x})(\mathrm{x}=3.6,5.2$ and $8.1 \mathrm{wt} \%)$ and compared to stoichiometric HAP (HA).27 As mentioned previously, 5-8 wt\% is the $\mathrm{CO}_{3}{ }^{2-}$ amount reported for bone mineral. To only assess the influence of the $\mathrm{CO}_{3}{ }^{2-}$ substitutions (i.e. exclude the occurring of confinement effect), the apatites were precipitated in the absence of a 3D collagen matrix. The different XRD diffractograms and TEM observations of HA, cHA-3.6, cHA-5.2, cHA-8.1, powders are displayed in Fig S3 and Fig. 4a, respectively. The line width of the diffraction peaks increases with the carbonate ions content (Fig.S3). The estimation of the lattice parameters and crystallite size (in the $a b$ plane and along the $c$ axis) were carried out through a Rietveld refinement (FullProf software ${ }^{41}$ (Tab. S3). In agreement with previous data reported on carbonated apatites, ${ }^{42}$ the $c / a$ ratio increases with the carbonate ions content. Moreover, the crystallites are elongated in the $c$-axis direction with a decrease in length when the $\mathrm{CO}_{3}{ }^{2-}$ content increases; $\mathrm{HA}$ is characterized by the largest crystallite size $(\sim 25 \mathrm{~nm} \times 25 \mathrm{~nm} \times 62 \mathrm{~nm})$ and cHA-8.1 by the smallest ( $\sim \mathrm{nm} \times 7 \mathrm{~nm} \times 10 \mathrm{~nm}$ ). According to TEM observations (Fig. 4a), it appears that the particles are actually single crystals. As described earlier, ${ }^{43}$ the size of the nanorod particles decreases and tends to a spherical morphology as soon as the carbonate content increases. This observation confirms the inhibitor role of carbonate ions during the growth of HAP particles. ${ }^{44}$ 
The structural modifications induced by the carbonate ions at the atomic level were assessed by ${ }^{1 \mathrm{H}}$ and ${ }^{31} \mathrm{P}$ MAS NMR spectroscopy on dry powders. The ${ }^{31} \mathrm{P}$ NMR MAS spectra of HA, cHA-3.6, cHA-5.2 and cHA-8.1 display one single resonance centered around 2.8-3.1 ppm (Fig. 4b). The ${ }^{31} \mathrm{P}$ spectrum of HA sample displays a sharper signal ( $\mathrm{LW}=80 \mathrm{~Hz}$ ) compared to carbonated samples. This is characteristic of a long-range order that is associated to a higher degree of crystallinity. The LW of the ${ }^{31}$ P MAS spectra increases with the carbonate ion content. In particular, a noticeable increase in line width is observed for cHA-8.1 (210 Hz) compared to cHA-5.2 $(116 \mathrm{~Hz})$ and cHA-3.6 (113 Hz). This indicates a higher local disorder reflected by an increase of the ${ }^{31} \mathrm{P}$ chemical shift distribution. It is worth mentioning that the $\delta\left({ }^{31} \mathrm{P}\right)$ shifts to higher chemical shift values with the carbonate ion content, which is in agreement with previously reported observations. ${ }^{45}$ Interestingly, cHA-8.1 also displays the shoulder on the left side of the resonance (arrow) as similarly observed for bone mineral, CHA-SBF and Coll/CHA(SBF). This observation suggests that this characteristic shoulder may be a consequence of the carbonate ions incorporation above $5.2 \mathrm{wt} . \%$.

Same conclusions can be drawn from the ${ }^{1} \mathrm{H}$ ssNMR analysis (Fig. 4c). The $\mathrm{LW}$ of the apatitic $\mathrm{OH}^{-}$ resonance $\left(\delta\left({ }^{1} \mathrm{H}\right)=0 \mathrm{ppm}\right)$ is increasing with the carbonate ion content due to the increase of the local disorder around hydroxyl ions. Moreover, a drastic modification of the LW is evidence for CHA-8.1 (compared to cHA-3.6 and cHA-5.2 that exhibit rather similar ${ }^{1} \mathrm{H}$ spectra) where the signal becomes asymmetric with a prominent shoulder on the left side highlighting the presence of distinct environments for the hydroxyl ions in the apatitic lattice. The broad proton resonance at $5 \mathrm{ppm}$ corresponding to adsorbed water is also increasing with the carbonate content probably due to the increase of the specific surface area of the particles exposed to atmospheric moisture.

Aside from the effect of carbonate ions on the local disorder of the apatitic core, we investigate their impact on the amorphous layer. The series of $2 \mathrm{D}{ }^{1} \mathrm{H}-31 \mathrm{P}$ HetCor experiment for HA, cHA-3.6, cHA-5.2 and cHA-8.1 (Fig. 4d-g) show a strong correlation at $\delta_{31 \mathrm{P}} \sim 3 \mathrm{ppm}$ and $\delta_{1 \mathrm{H}}=$ 0 ppm characteristic of apatitic $\mathrm{PO}_{4}{ }^{3-}$ ions correlating with hydroxyls ions. A broader correlation centered at $\delta_{1 \mathrm{H}} \sim 5 \mathrm{ppm}$ is arising with the increase of the carbonate ions content that corresponds to non-apatitic surface species according to the above results. In agreement with measurements on the dry state of the samples, the corresponding ${ }^{1} \mathrm{H}$ signal is spread over a large range of chemical shifts (from 5 to $15 \mathrm{ppm}$ for cHA-8.1). This is in contrast to previous hydrated samples. They were hydrated and the whole signal merges at $4.85 \mathrm{ppm}$ due to a fast proton chemical exchange process involving water molecules. These data strongly suggest that the incorporation of carbonate ions is directly responsible for the formation of the amorphous surface layer. Furthermore, the line width of the resonance corresponding to apatitic phosphate is increasing with the carbonates ion content (Table 1). This increase of the chemical shift 
distribution could result from the substitution of carbonate ions in the apatitic lattice. $45 \mathrm{~A}$ similar behavior is observed for non-apatitic phosphates suggesting also the presence of carbonate ions in the outer layer ${ }^{8}$ (Table 1 ).

The simulations of the ${ }^{31}$ P MAS spectra confirm an increase of the relative amount of phosphate ions in the disordered domain compared to apatitic phosphates (up to 65\% for cHA-8.1) (Table 1). If the thickness of the surface layer remains unchanged, this trend can be related to the decrease in particle size and thus in the relative amount of the core species compared to surface species.

The results show that carbonate ions are directly involved in the formation of the outer disordered domain proposed as an ACP layer in synthetic ${ }^{10}$ and bone apatites. ${ }^{8}$ In addition to their effect on size, ${ }^{44}$ carbonate ions influence the ACP-to-crystalline ratio of the apatite particles. A related effect may occur for bone apatite where a high amount of carbonate ions substitutions is reported for both young and mature crystals (> $6 \mathrm{wt} . \%$ ).

Keeping in mind the higher local disorder in the apatite lattice for Coll/CHA compared to CHA, we propose that a higher amount of $\mathrm{CO}_{3}{ }^{2-}$ might be incorporated in the apatitic lattice of Coll/CHA. Since the amount of carbonate ions in the mother solution is identical for both samples, this difference can result from a local increase of the carbonate ions concentration within the dense collagen matrix. This may occur through electrostatic attractive forces induced by positive net charges close to the C-terminal domain of the collagen molecules. ${ }^{46}$

The comparison between CHA-SBF and cHA-8.1 is particularly informative. The initial $\mathrm{CO}_{3}{ }^{2-}$ concentration in SBF is relatively low (300 times less than the mother solution for cHA-8.1), but the resulting particles possess a similar carbonate ions content (7 wt.\%). The amount of carbonate ions incorporated may be mediated by the carbonate to phosphate initial ratio $\left(\mathrm{CO}_{3} / \mathrm{P}\right.$ $=4.2$ vs. $\mathrm{CO}_{3} / \mathrm{P}=1$ for $\mathrm{CHA}-\mathrm{SBF}$ and $\mathrm{cHA}-8.1$, respectively). The fact that the $\mathrm{CO}_{3} / \mathrm{P}$ ratio is even more important in the human plasma (up to 27) strengthens this assumption. Other ions from SBF described as substitution ions in the Hap lattice $\left(\mathrm{Na}^{+}, \mathrm{K}^{+}, \mathrm{Cl}\right)$ might also help for the insertion of carbonate ions.

\section{Conclusion}

In summary, we demonstrate that both, collagen confinement and $\mathrm{CO}_{3}{ }^{2-}$ substitutions influence the local disorder of the apatitic core and induce the presence of an ACP layer. The impact of the 3D confinement in a dense collagen matrix might be of importance at the first stage 
of bone mineral formation. This 3D confinement impacts both the ${ }^{31} \mathrm{P}$ and the ${ }^{1} \mathrm{H}$ NMR response for HAP particles synthesized in an aqueous medium where $\mathrm{C} / \mathrm{P}=1$. In that case, we observe a higher proportion of the hydrated amorphous layer as well as a higher structural disorder of the apatitic core in presence of the collagen matrix that might be explained by a local increase of carbonate ions concentration within the gap region due to a positive net charge close to the Cterminal domain of the collagen molecules. We also show that, in addition to a collagen confinment, ${ }^{22}$ the carbonate substitutions may also interfere in mediating the particle sizes in vivo. The proportion of the ACP layer relative to the crystalline core increases with the $\mathrm{CO}_{3}{ }^{2-}$ content and is concomitant with the decrease of the particle size. This latter characteristic may control the degree of crystallinity of newly formed bone apatite nanocrystals. An incorporation of $~ 7-8$ wt.\% carbonate ions allows these apatitic models to have similar spectral characteristics found in bone mineral.

\section{Acknowledgments}

We thank IMM Recherche specially Dr. L. Behr for providing the fresh bone samples, A. Anglo and C. Illoul for preparation of bone thin sections for TEM observations, Dr. Ö. Sel and Dr. J. Seto for insightful discussions and critical suggestions. This work was supported by the Agence Nationale de la Recherche (ANR) through the ANR- 09-BLAN-0120-01 « NanoShap » program.

\section{References}

1. M. J. Glimcher, in Medical Mineralogy and Geochemistry, eds. N. Sahai and M. A. A.

Schoonen, 2006, vol. 64, pp. 223-282.

2. S. Fitton-Jackson, Proc. Roy. Soc. London, Ser. B, 1957, 146, 270-280.

3. S. Weiner and W. Traub, FEBS Letters, 1986, 206, 262-266.

4. W. J. Landis, K. J. Hodgens, J. Arena, M. J. Song and B. F. McEwen, Microsc. Res. Tech., 1996, 33, 192-202.

5. H. Frenkel-Mullerad and D. Avnir, J. Am. Chem. Soc., 2005, 127, 8077-8081.

6. G. K. Hunter and H. A. Goldberg, Proc. Natl. Acad. Sci. USA, 1993, 90, 8562-8565.

7. C. Rey, C. Combes, C. Drouet and M. J. Glimcher, Osteoporosis Int., 2009, 20, 1013-1021.

8. Y. Wang, S. Von Euw, F. M. Fernandes, S. Cassaignon, M. Selmane, G. Laurent, G. Pehau-

Arnaudet, C. Coelho, L. Bonhomme-Coury, M.-M. Giraud-Guille, F. Babonneau, T. Azaïs and N. Nassif, Nat. Mater. In press, 2013.

9. R. Legros, N. Balmain and G. Bonel, J. Chem. Res., 1986, 8-9.

10. C. Rey, C. Combes, C. Drouet, H. Sfihi and A. Barroug, Mater. Sci. Eng. C, 2007, 27, 198-205.

11. A. K. Bembey, A. J. Bushby, A. Boyde, V. L. Ferguson and M. L. Oyen, J. Mater. Res., 2006, 21, 1962-1968.

12. S. C. Cowin, J. Biomech., 1999, 32, 217-238. 
13. W. Kolodziejski, in New Techniques in Solid-State NMR, ed. J. Klinowski, Springer Berlin / Heidelberg, 2004, vol. 246, pp. 235-270.

14. J. Xu, P. Zhu, Z. Gan, N. Sahar, M. Tecklenburg, M. D. Morris, D. H. Kohn and A.

Ramamoorthy, J. Am. Chem. Soc., 2010, 132, 11504-11509.

15. P. Zhu, J. Xu, N. Sahar, M. D. Morris, D. H. Kohn and A. Ramamoorthy, J. Am. Chem. Soc., 2009, 131, 17064-17065.

16. Y.-Y. Hu, A. Rawal and K. Schmidt-Rohr, Proc. Natl. Acad. Sci. USA, 2010, 107, 22425-22429.

17. O. Nikel, D. Laurencin, C. Bonhomme, G. E. Sroga, S. Besdo, A. Lorenz and D. Vashishth, J. Phys. Chem. C, 2012, 116, 6320-6331.

18. R. K. Rai and N. Sinha, J. Phys. Chem. C, 2011, 115, 14219-14227.

19. E. R. Wise, S. Maltsev, M. E. Davies, M. J. Duer, C. Jaeger, N. Loveridge, R. C. Murray and D. G. Reid, Chem. Mater., 2007, 19, 5055-5057.

20. A. H. Roufosse, W. P. Aue, J. E. Roberts, M. J. Glimcher and R. G. Griffin, Biochemistry, 1984, 23, 6115-6120.

21. J. P. Yesinowski and H. Eckert, J. Am. Chem. Soc., 1987, 109, 6274-6282.

22. Y. Wang, T. Azaïs, M. Robin, A. Vallée, C. Catania, P. Legriel, G. Pehau-Arnaudet, F. Babonneau, M.-M. Giraud-Guille and n. Nassif, Nat. Mater., 2012, 11, 724-733.

23. L. Wang and G. H. Nancollas, Chem. Rev., 2008, 108, 4628-4669.

24. M. M. G. Guille, C. Helary, S. Vigier and N. Nassif, Soft Matter, 2010, 6, 4963-4967.

25. J. Silvent, N. Nassif, C. Helary, T. Azais, J. Y. Sire and M. M. G. Guille, PLoS One, 2013, 8, e57344.

26. N. Nassif, F. Martineau, O. Syzgantseva, F. Gobeaux, M. Willinger, T. Coradin, S. Cassaignon, T. Azais and M. M. Giraud-Guille, Chem. Mater., 2010, 22, 3653-3663.

27. S. Takemoto, Y. Kusudo, K. Tsuru, S. Hayakawa, A. Osaka and S. Takashima, J. Biomed. Mater. Res. Part A, 2004, 69A, 544-551.

28. C. Bonhomme, C. Coelho, N. Baccile, C. Gervais, T. Azais and F. Babonneau, Acc. Chem. Res., 2007, 40, 738-746.

29. G. Cho, Y. Wu and J. L. Ackerman, Science, 2003, 300, 1123-1127.

30. S. Maltsev, M. J. Duer, R. C. Murray and C. Jaeger, J. Mater. Sci., 2007, 42, 8804-8810.

31. R. A. Santos, R. A. Wind and C. E. Bronnimann, J. Magn. Reson. B, 1994, 105, 183-187.

32. C. Jäger, T. Welzel, W. Meyer-Zaika and M. Epple, Magn. Reson. Chem., 2006, 44, 573-580.

33. S. H. Rhee and J. Tanaka, J. Mater. Sci-Mater. Med., 2000, 11, 449-452.

34. Y. Wang, J. Silvent, M. Robin, F. Babonneau, A. Meddahi-Pelle, N. Nassif and M. M. Giraud Guille, Soft Matter, 2011, 7, 9659-9664.

35. A. Hodge and J. Petruska, in Aspects of Protein Structure, ed. G. Ramachandran, Academic Press, 1963 pp. 289-300.

36. N. Folliet, C. Roiland, S. Begu, A. Aubert, T. Mineva, A. Goursot, K. Selvaraj, L. Duma, F. Tielens, F. Mauri, G. Laurent, C. Bonhomme, C. Gervais, F. Babonneau and T. Azais, J. Am. Chem. Soc., 2011, 133, 16815-16827.

37. A. Kaflak-Hachulska, A. Samoson and W. Kolodziejski, Calcif. Tissue Int., 2003, 73, 476-486.

38. E. Davies, M. J. Duer, S. E. Ashbrook and J. M. Griffin, J. Am. Chem. Soc., 2012, 134, 1250812515.

39. C. F. Nawrot, D. J. Campbell, J. K. Schroeder and M. Van Valkenburg, Biochemistry, 1976, 15, 3445-3449.

40. C. K. Loong, C. Rey, L. T. Kuhn, C. Combes, Y. Wu, S. H. Chen and M. J. Glimcher, Bone, 2000, 26, 599-602.

41. J. Rodríguez-Carvajal, Physica B: Condensed Matter, 1993, 192, 55-69.

42. D. G. Nelson and J. D. Featherstone, Calcif. Tissue Int., 1982, 34, S69-S81.

43. D. G. A. Nelson, J. dental Res., 1981, 60, 1621-1629.

44. R. Z. Legeros, O. R. Trautz, J. P. Legeros, E. Klein and W. P. Shirra, Science, 1967, 155, 1409-

1411. 
45. W. P. Aue, A. H. Roufosse, M. J. Glimcher and R. G. Griffin, Biochemistry, 1984, 23, 61106114.

46. F. Nudelman, K. Pieterse, A. George, P. H. H. Bomans, H. Friedrich, L. J. Brylka, P. A. J. Hilbers, G. de With and N. A. J. M. Sommerdijk, Nat. Mater., 2010, 9, 1004-1009. 


\begin{tabular}{|c|c|c|c|c|c|c|c|}
\hline \multirow[b]{2}{*}{ Sample } & \multicolumn{2}{|c|}{ 31P apatitic core } & \multicolumn{2}{|c|}{$\begin{array}{l}\text { 31P amorphous } \\
\text { layer }\end{array}$} & \multirow{2}{*}{$\begin{array}{l}\text { Ratio } \\
\text { apatitic/amophous } \\
{ }^{31} \mathrm{P}( \pm 5 \%)\end{array}$} & \multicolumn{2}{|c|}{${ }^{1} \mathrm{H}$ apatitic core } \\
\hline & $\begin{array}{l}\delta(31 \mathrm{P}) \pm \\
0.1 \mathrm{ppm}\end{array}$ & $\begin{array}{l}\mathrm{LW} \pm \\
20 \mathrm{~Hz}\end{array}$ & $\begin{array}{l}\delta(31 \mathrm{P}) \pm \\
0.1 \\
\mathrm{ppm}\end{array}$ & $\begin{array}{l}\mathrm{LW} \pm \\
20 \mathrm{~Hz}\end{array}$ & & $\begin{array}{l}\delta\left({ }^{1} \mathrm{H}\right) \pm \\
0.1 \\
\mathrm{ppm}\end{array}$ & $\begin{array}{l}\mathrm{LW} \pm \\
10 \mathrm{~Hz}\end{array}$ \\
\hline CHA & 3.0 & 140 & 3.1 & 430 & $65 / 35$ & -0.2 & 160 \\
\hline Coll/CHA & 3.1 & 200 & 3.1 & 490 & $40 / 60$ & -0.2 & 330 \\
\hline Bone & 3.1 & 270 & 3.2 & 640 & $55 / 45$ & $0.0^{\mathrm{a}}$ & $400^{\mathrm{b}}$ \\
\hline Coll/CHA(SBF) & 3.1 & 285 & 3.2 & 660 & $55 / 45$ & $0.0^{\mathrm{a}}$ & $430^{\mathrm{b}}$ \\
\hline CHA-SBF & 3.1 & 290 & 3.2 & 660 & $55 / 45$ & $0.0^{\mathrm{a}}$ & $430^{\mathrm{b}}$ \\
\hline HA & 2.8 & 80 & - & - & $100 / 0$ & -0.3 & 140 \\
\hline cHA-3.6 & 2.8 & 110 & 2.9 & 280 & $70 / 30$ & -0.3 & 170 \\
\hline cHA-5.2 & 2.9 & 115 & 3.1 & 330 & $50 / 50$ & -0.3 & 175 \\
\hline cHA-8.1 & 3.0 & 210 & 3.0 & 370 & $35 / 65$ & $0.0^{\mathrm{a}}$ & 342 \\
\hline
\end{tabular}

a asymmetric line shape, b global linewidth

Table 1 

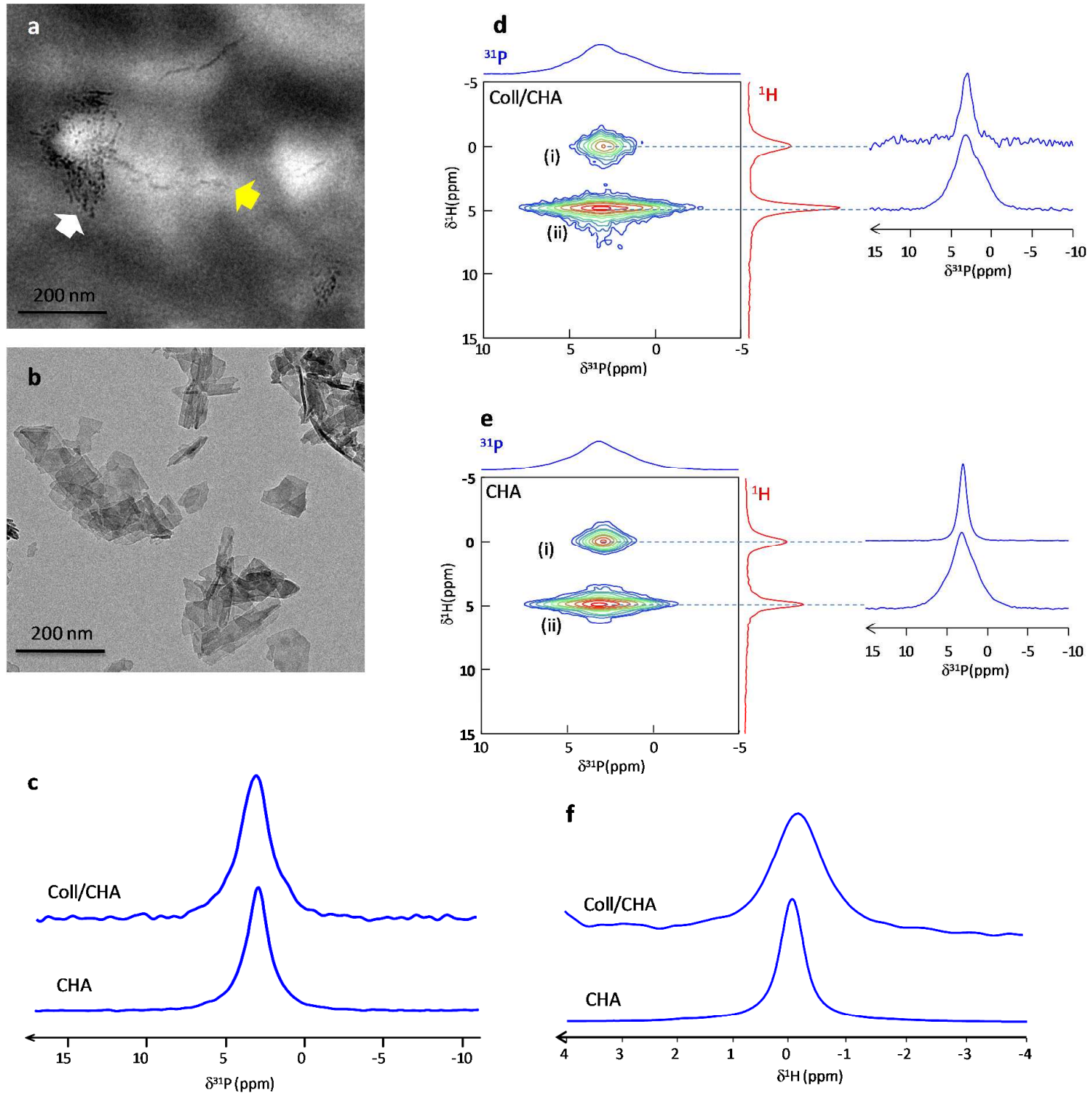

Figure 1: a) and b) TEM micrographs of Coll/CHA and CHA. c) ${ }^{31} \mathrm{P}$ MAS NMR quantitative spectra of Coll/CHA and CHA. d) and e) 2D ${ }^{1} \mathrm{H}-31 \mathrm{P}$ HetCor spectra of Coll/CHA and wet CHA displaying the two distinct domains corresponding to (i) the apatitic core and (ii) the hydrated disordered layer. f) $\left\{{ }^{1} \mathrm{H}-{ }^{31} \mathrm{P}\right\}{ }^{1} \mathrm{H}$ Double CP spectra of Coll/CHA and CHA. 

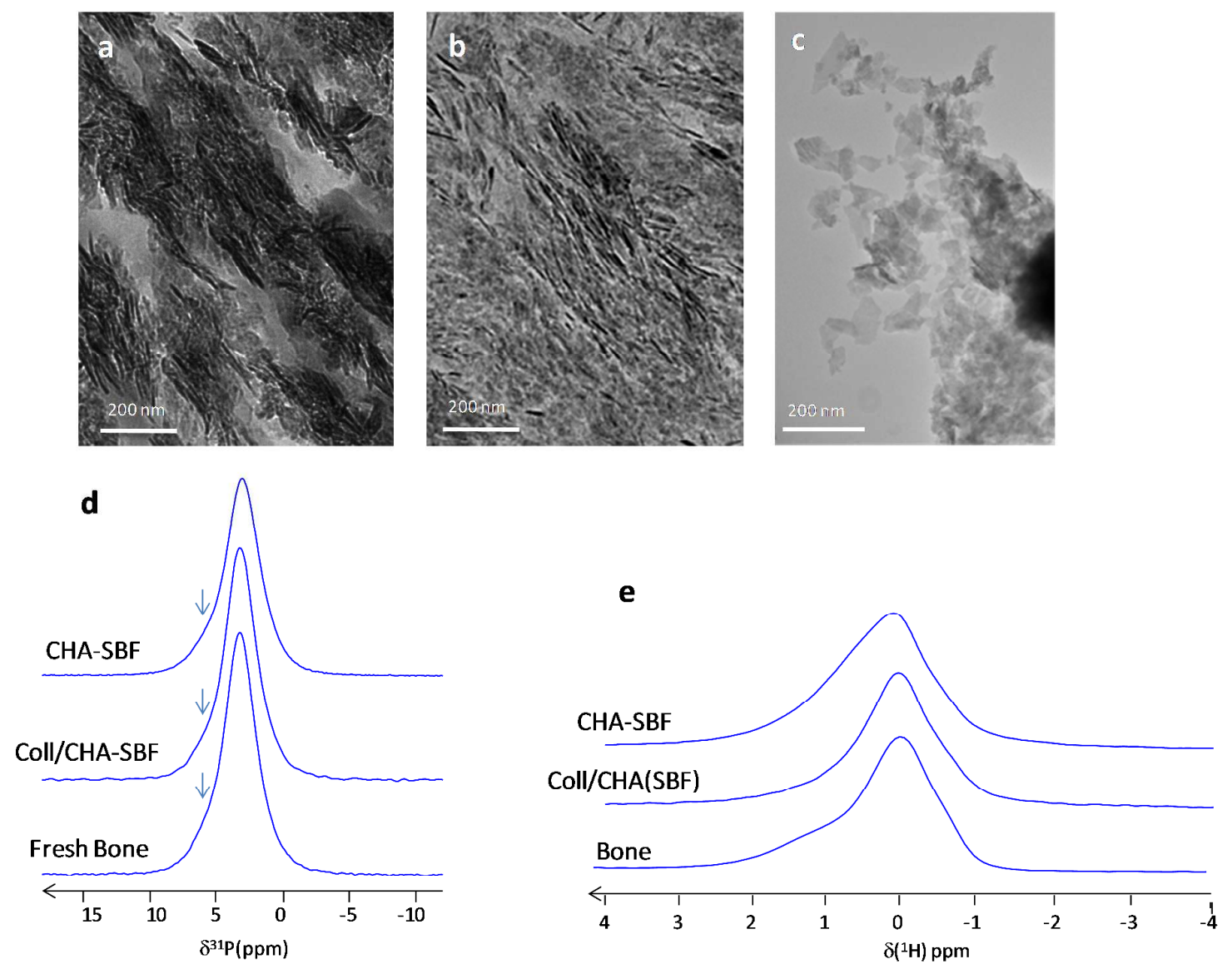

Figure 2 : a) b) c) TEM micrographs of Coll/CHA(SBF), bone and CHA-SBF, and, respectively. d) ${ }^{31} \mathrm{P}$ MAS quantitative spectra of CHA-SBF, Coll/CHA(SBF) and fresh bone. The arrows display the characteristic shoulder of bone mineral ${ }^{31} \mathrm{P}$ spectrum. e) $\left\{{ }^{1} \mathrm{H}^{31} \mathrm{P}\right\}^{1} \mathrm{H}$ Double CP spectra of CHA$\mathrm{SBF}$, Coll/CHA(SBF) and intact bone $\left(\mathrm{CT}_{1}=\mathrm{CT}_{2}=10 \mathrm{~ms}\right.$ for $\mathrm{CHA}-\mathrm{SBF}, \mathrm{CT}_{1}=\mathrm{CT}_{2}=15 \mathrm{~ms}$ for bone and Coll/CHA(SBF)). 

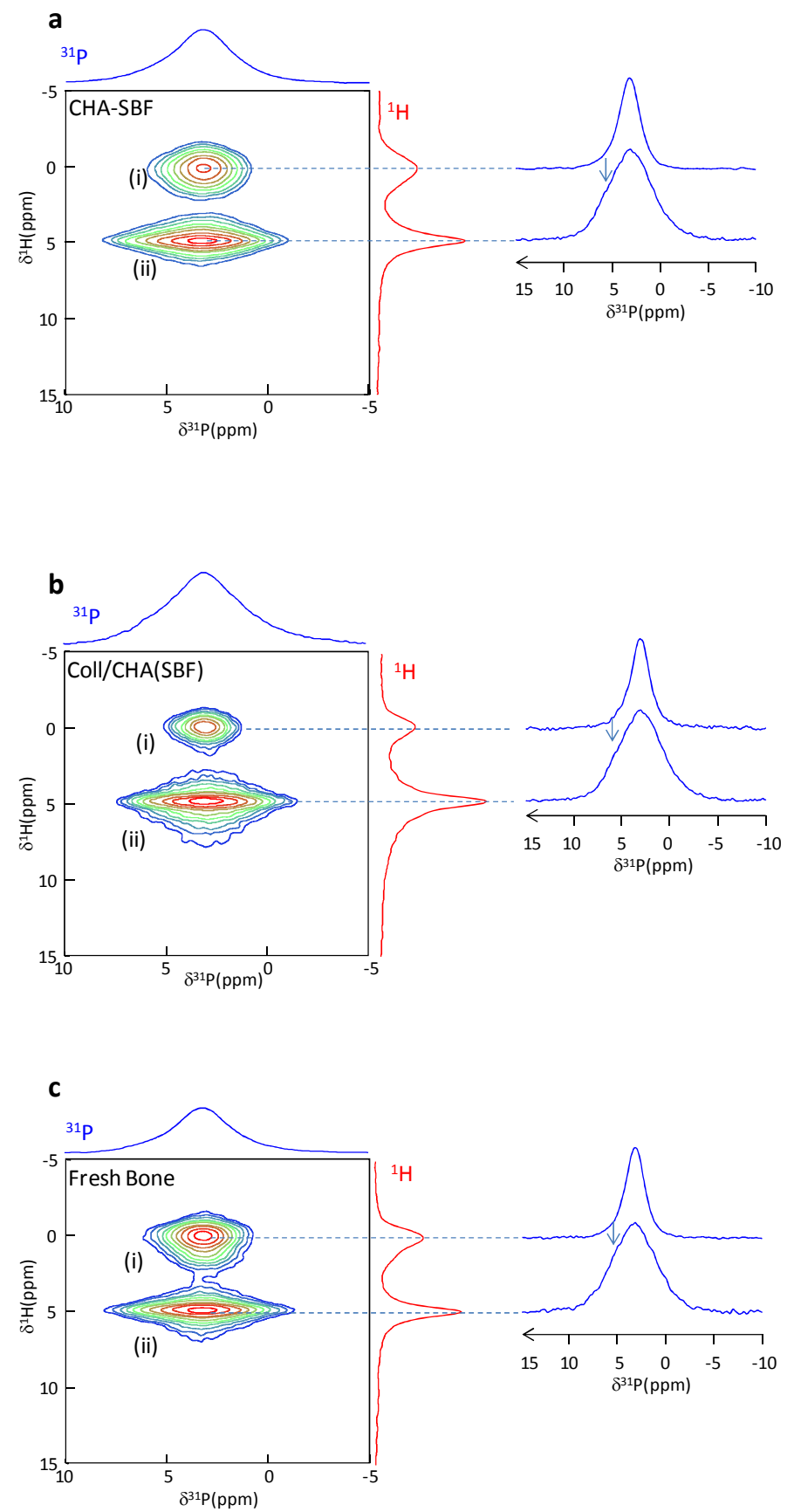

Figure 3: a), b) and c) 2D ${ }^{1} \mathrm{H}-31 \mathrm{P}$ HetCor spectra of wet CHA-SBF, Coll/CHA(SBF) and fresh bone displaying the two distinct domains corresponding to (i) the apatitic core and (ii) the hydrated disordered layer. The arrows on the ${ }^{31} \mathrm{P}$ projections indicate the characteristic shoulder of bone mineral ${ }^{31} \mathrm{P}$ spectrum. 
a

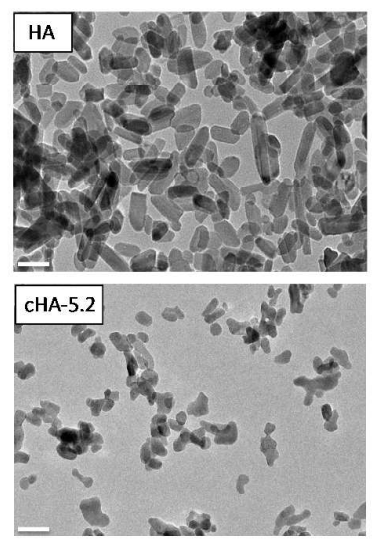

b

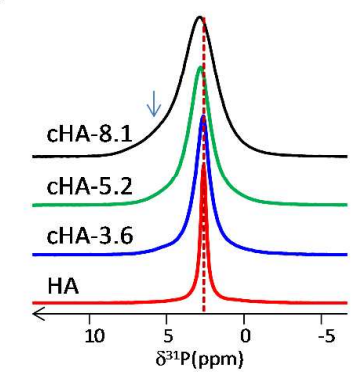

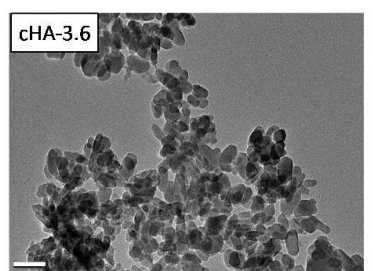
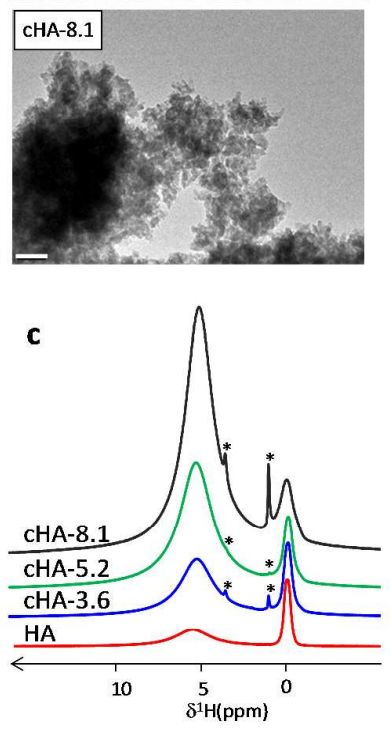

d

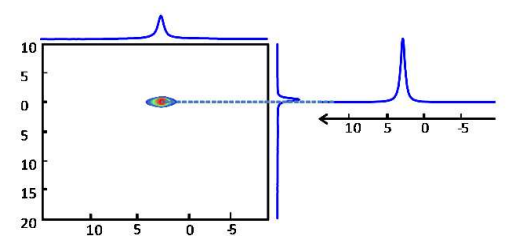

e

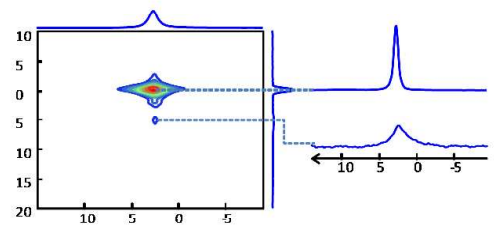

f

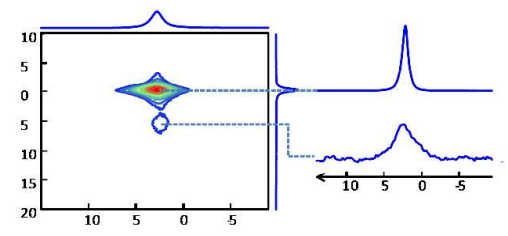

g

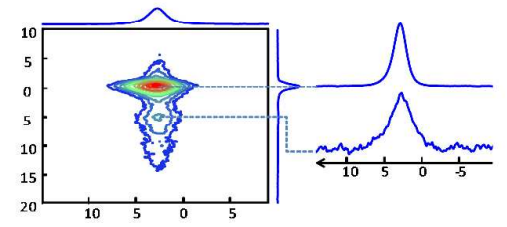

Figure 4: a) TEM micrographs of HA, cHA-3.6, cHA-5.2, cHA-8.1 (scale bar = $100 \mathrm{~nm}$ ). b) ${ }^{31} \mathrm{P}$ MAS quantitative spectra of HA, cHA-3.6, cHA-5.2, cHA-8.1. c) ${ }^{1} \mathrm{H}$ MAS spectra of HA, cHA-3.6, cHA-5.2, cHA-8.1 (* residual ethanol) and d-g) 2D ${ }^{1} \mathrm{H}-{ }^{31} \mathrm{P}$ HetCor spectra of HA, cHA-3.6, cHA-5.2, cHA-8.1 (the samples are studied in the dry state). 


\title{
Supplementary Informations
}

\section{Impact of Collagen Confinement vs. Ionic Substitutions on the local disorder in Bone Apatites}

\author{
Yan Wang, Stanislas Von Euw, Guillaume Laurent, Charlène Crevant, Laure Bonhomme-Coury, \\ Marie-Madeleine Giraud-Guille, Florence Babonneau, Nadine Nassif* and Thierry Azaïs* \\ UPMC Univ Paris 06 \& CNRS, UMR 7574, Chimie de la Matière Condensée de Paris, Collège de \\ France, 11 Place Marcelin Berthelot, F-75005 Paris, France
}




\begin{tabular}{|c|c|c|c|c|c|c|c|c|c|c|}
\hline $\begin{array}{l}\text { Concentration } \\
(\mathrm{mM})\end{array}$ & $\begin{array}{l}\mathrm{CaCl}_{2} \\
2 \mathrm{H}_{2} \mathrm{O}\end{array}$ & $\mathrm{NaH}_{2} \mathrm{PO}_{4}$ & $\mathrm{~K}_{2} \mathrm{HPO}_{4}$ & $\mathrm{NaHCO}_{3}$ & $\mathrm{NaCl}$ & $\mathrm{KCl}$ & $\begin{array}{l}\mathrm{MgCl}_{2} \\
6 \mathrm{H}_{2} \mathrm{O}\end{array}$ & $\mathrm{Na}_{2} \mathrm{SO}_{4}$ & $\begin{array}{c}\left(\mathrm{CH}_{2} \mathrm{OH}\right)_{3} \\
\mathrm{CNH}_{2}\end{array}$ & $\begin{array}{l}\text { Ionic } \\
\text { strength } \\
\text { (mM) }\end{array}$ \\
\hline $\begin{array}{c}\mathrm{CHA} \\
\text { solution* }\end{array}$ & 46.1 & 13.8 & - & 13.8 & - & - & - & - & - & 165.9 \\
\hline $\begin{array}{c}\text { SBF } \\
\text { solution* }\end{array}$ & 2.5 & - & 1 & 4.2 & 142 & 3 & 1.5 & 0.5 & - & 165.7 \\
\hline $\begin{array}{c}\text { SBF 1.5 } \\
\text { solution } \\
(\mathrm{pH}=7.4)\end{array}$ & 3.8 & - & 1.5 & 6.3 & 213 & 4.5 & 2.3 & 0.75 & 10 & 248.9 \\
\hline
\end{tabular}

Table S1. Concentration of salt precursors used in mineralized collagen matrices syntheses. *The solutions were prepared in $500 \mathrm{mM}$ acetic acid. 


\begin{tabular}{|c|c|}
\hline HA & $500 \mathrm{mM} \mathrm{Ca}\left(\mathrm{NO}_{3}\right)_{2} 4 \mathrm{H}_{2} \mathrm{O} ; 300 \mathrm{mM}\left(\mathrm{NH}_{4}\right)_{2} \mathrm{HPO}_{4}$ \\
\hline cHA-3.6 & $500 \mathrm{mM} \mathrm{Ca}\left(\mathrm{NO}_{3}\right)_{2} 4 \mathrm{H}_{2} \mathrm{O} ; 300 \mathrm{mM}\left(\mathrm{NH}_{4}\right)_{2} \mathrm{HPO}_{4} ; 75 \mathrm{mM} \mathrm{NaHCO}$ \\
\hline cHA-5.2 & $\begin{array}{l}500 \mathrm{mM} \mathrm{Ca}\left(\mathrm{NO}_{3}\right)_{2} \quad 4 \mathrm{H}_{2} \mathrm{O} ; 300 \mathrm{mM}\left(\mathrm{NH}_{4}\right)_{2} \mathrm{HPO}_{4} ; 150 \mathrm{mM} \\
\mathrm{NaHCO}_{3}\end{array}$ \\
\hline cHA-8.1 & $\begin{array}{l}500 \mathrm{mM} \mathrm{Ca}\left(\mathrm{NO}_{3}\right)_{2} 4 \mathrm{H}_{2} \mathrm{O} ; 300 \mathrm{mM}\left(\mathrm{NH}_{4}\right)_{2} \mathrm{HPO}_{4} ; 300 \mathrm{mM} \\
\mathrm{NaHCO}_{3}\end{array}$ \\
\hline
\end{tabular}

Table S2: Concentration of salt precursors for the synthesis of HA, cHA-3.6, cHA-5.2 and cHA-8.1 


\begin{tabular}{|c|c|c|}
\hline Sample & $\boldsymbol{a}(\AA)$ & $\boldsymbol{c}(\AA)$ \\
\hline HA & $9.425 \pm 0.002$ & $6.878 \pm 0.001$ \\
\hline cHA-3.6 & $9.430 \pm 0.001$ & $6.885 \pm 0.001$ \\
\hline cHA-5.2 & $9.420 \pm 0.001$ & $6.897 \pm 0.001$ \\
\hline cHA-8.1 & $9.414 \pm 0.003$ & $6.909 \pm 0.002$ \\
\hline
\end{tabular}

\begin{tabular}{|c|c|c|}
\hline Crystallite size & $\boldsymbol{a} \boldsymbol{b}(\mathbf{n m})$ & $\boldsymbol{c}(\mathbf{n m})$ \\
\hline HA & 25 & 62 \\
\hline cHA-3.6 & 20 & 30 \\
\hline cHA-5.2 & 12 & 19 \\
\hline cHA-8.1 & 7 & 10 \\
\hline
\end{tabular}

Table S3: Lattice parameters and crystallite size of HA, cHA-3.6, cHA-5.2 and cHA-8.1. 


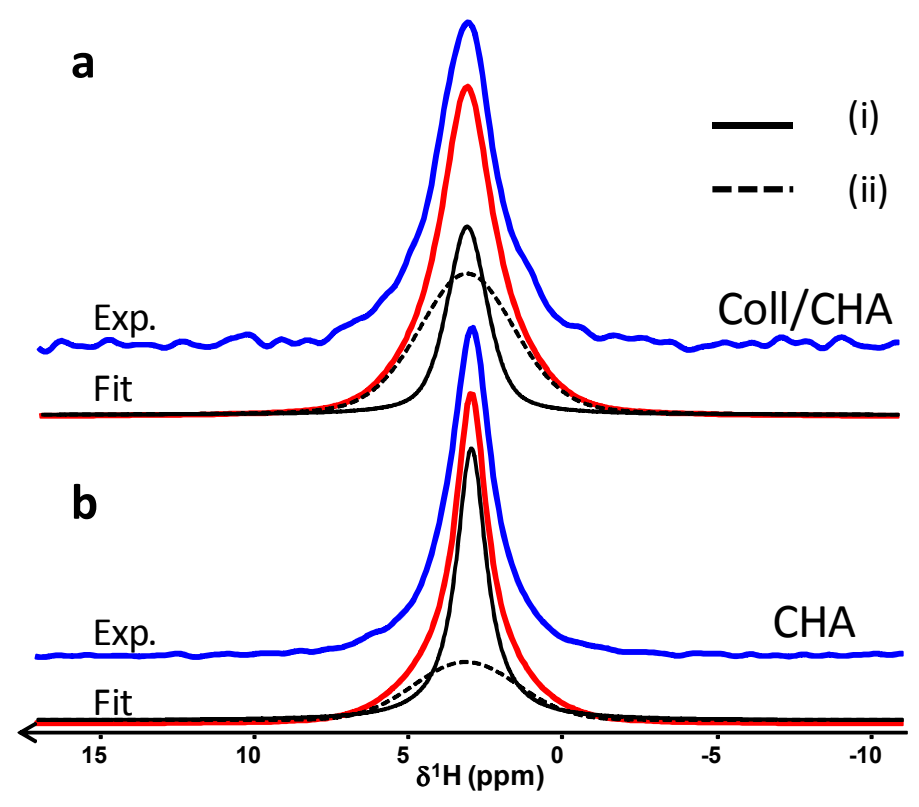

Figure S1: a) and b) quantitative ${ }^{31} \mathrm{P}$ MAS spectra (blue) of Coll/CHA and CHA and the corresponding fitting (red) starting from the line shapes extracted from the $2 \mathrm{D}{ }^{1} \mathrm{H}-{ }^{31} \mathrm{P}$ HetCor spectra (Fig. 1d \& 1e) and corresponding to apatitic phosphates (i) and disordered phosphates (ii). 


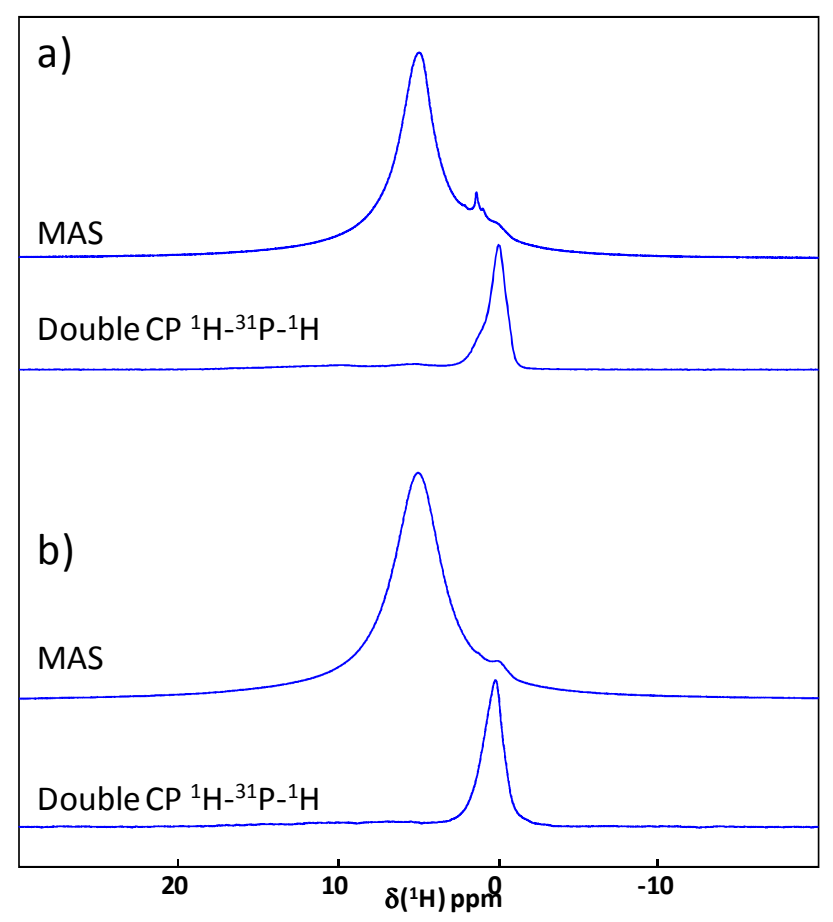

Figure S2: ${ }^{1} \mathrm{H}$ quantitative MAS and $\left\{{ }^{1} \mathrm{H}-{ }^{31} \mathrm{P}\right\}{ }^{1} \mathrm{H}$ Double $\mathrm{CP}$ spectra of a) dry bone $\left(\mathrm{CT}_{1}=\mathrm{CT}_{2}=15\right.$ $\mathrm{ms})$ and b) CHA-SBF $\left(\mathrm{CT}_{1}=\mathrm{CT}_{2}=10 \mathrm{~ms}\right)$. The $\left\{{ }^{1} \mathrm{H}^{31} \mathrm{P}\right\}{ }^{1} \mathrm{H}$ Double $\mathrm{CP}$ allows the spectral edition of the apatitic $\mathrm{OH}^{-}$ion resonance both for bone and CHA-SBF whereas the ${ }^{1} \mathrm{H}$ MAS spectra are blurred by unwanted ${ }^{1} \mathrm{H}$ signals from adsorbed water and extra cellular matrix (including collagen and non collageneous proteins) in case of bone. 


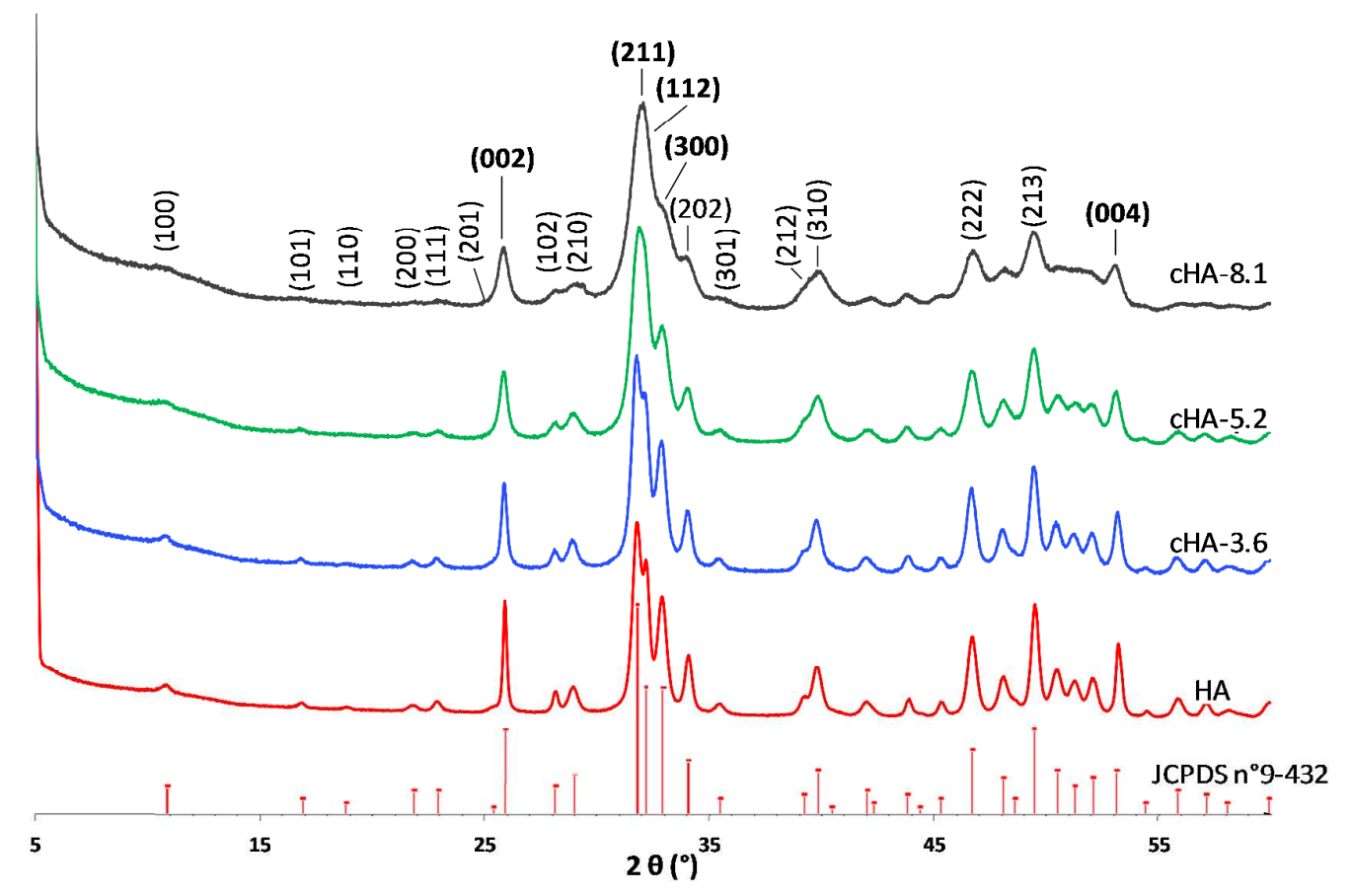

Figure S3 : XRD patterns of HA, cHA-3.6, cHA-5.2 and cHA-8.1 